\title{
Introducing College Freshmen to Business History
}

The University of Nebraska is introducing a freshman course in "The Evolution of Business and Capitalism" to replace a survey course in the economic history of England and the United States. The change in title will become effective in September, 1948, although the new content has been in use on an experimental basis for nearly a year. The stages in the development of the course may be of interest to other teachers in economic and business history.

The course gives three semester-hours' credit and is required of all freshmen who are candidates for a degree from the College of Business Administration. During the current year an increasing number of students from other colleges within the University also have enrolled.

For a number of years the course was a brief survey of the economic history of England and the United States with The Development of Economic Society by Modlin and De Vyver as the textbook. Very little other reading was required. The course was not successful. Returning veteran students especially were dissatisfied. The textbook has the limitation of any brief volume that would attempt to survey the economic development of England and the United States since the eleventh century. To many students the subject appeared to be related only remotely to their idea of more "practical courses" for a business career. Furthermore, the subject was partially covered in the general history courses required of all students.

During the summer of 1946 the teaching staff of the course and the chairman of the Department of Economics, Dr. Clarence E. McNeill, considered various revisions of the course content. They agreed that the best proposal for a three-hour freshman course was business history with emphasis upon the development of capitalism. The only book suitable as a text is Business and Capitalism by Professor N. S. B. Gras. The opinion of the staff at that time, however, was that this book was too advanced for most freshman students. 
At least it was quite a departure from the textbook by Modlin and De Vyver. Nevertheless, the idea did appear worth some experimentation.

Consequently, in the first semester of 1946-47 there were added to the textbook readings in Modlin and De Vyver's textbook six assignments from Gras' Business and Capitalism and several lessons from H. U. Faulkner's Economic History of the United States. In the second semester these were retained, and several case studies from the Casebook in American Business History by N. S. B. Gras and Henrietta M. Larson were also assigned.

As the year progressed, the faculty appreciated that this was not a fair test of the volumes by Professors Gras and Larson. Furthermore, the combination of the several books proved unsatisfactory. It was evident, however, that the students were interested in the emphasis on capitalism and the development of the modern business man. The staff then agreed that the content of the course should be changed on an experimental basis to the history of business and capitalism.

Business and Capitalism by Professor Gras was selected as the basic textbook. Selected cases from the Casebook in American Business History were assigned as library readings. I wrote a "Workbook in the Evolution of Capitalism" as an introduction and guide for the freshmen to these books that appeared otherwise too mature. A description of the workbook will give the main features of the course as it has been offered since June, 1947.

There are thirty units, averaging two units for each three one-hour class meeting. For the most part, the titles are taken from Business and Capitalism, together with selected case studies. The general contents of the workbook and the reading assignments are as follows:

\section{Part One. Petty Capitalism:}

\section{The Origin of Private Business}

I. Introduction. (Business and Capitalism, vii-xiii, 1-3, 27-29; Casebook, 3-4.)

II. Pre-Business Capitalism. (B. and C., 1-26.)

III. Petty Capitalism: I. (B. and C., 30-50.)

IV. Petty Capitalism: II. (B. and C., 51-66; Casebook, 4-5.) 


\section{Part Two. Mercantile Capitalism: Birth of Control in Private Business}

V. The Sedentary Merchant. (B. and C., 67-85; Casebook, 5-7.)

VI. Factors of Mercantile Capitalism. (B. and C., 85-92, 151-157.)

VII. Industry and Trading. (B. and C., 92-119.)

VIII. Case Study: Sir Thomas Smythe and the Virginia Company. (Casebook, 29-44.)

IX. Case Study: John Jacob Astor. (Casebook, 76-97.)

Part Three. Mercantile Capitalism:

Maturity with a Tendency to Disintegrate

X. Merchants' Policies and Organizations. (B. and C., 120-132.)

XI. Case Study: Mercantilism. (Casebook, 98-99, 102-115.)

XII. Variations from the Merchant Capitalist Type. (B. and C., 132-151.)

XIII. Appraisal of Mercantile Capitalism. (B. and C., 157-174.)

Part Four. Industrial Capitalism:

The Triumph of Firm Specialization in Big Business

XIV. Rise of Industrial Capitalism. (B. and C., 175-195; Casebook, 8-10.)

XV. Early Industrial Development: Case Study of Samuel Slater. (Casebook, 209-230.)

XVI. Marketing; Business Agents. (B. and C., 195-214.)

XVII. Case Study: The Development of Internal Markets; Metropolitan Economy. (Casebook, 385-403.)

XVIII. Case Study: The Second Bank of the United States. (Casebook, 171-183.)

XIX. Secular Trends in Prices and Profits. (B. and C., 215-218; Casebook, 662-663, 706-725.)

XX. Investment Capital under Early Industrial Capitalism. (B. and C., 218-223; Casebook, 296-323, on Jay Cooke \& Company.)

XXI. Railroad Management: Case Study on James J. Hill. (Casebook, 403-418.)

XXII. Appraisal of Industrial Capitalism. (B. and C., 224-246.)

Part Five. Financial Capitalism:

The Money Middleman Influences or Controls Business

XXIII. Financial Capitalists; Flow of Capital. (B. and C., 246-266; Casebook, 10-12.)

XXIV. Some Activities of Financial Capitalists. (B. and C., 266-297.)

XXV. Secular Trends and Financial Capitalism. (B. and C., 297-304.)

XXVI. Strength and Weakness of Financial Capitalism. (B. and C., 305-324.) 
Part Six. National Capitalism:

\section{Political instead of Financial Control of Private Capital}

XXVII. The Nature of National Capitalism. (B. and C., 323-338; Casebook, 12-15.)

XXVIII. Fascism; Naziism; The American New Deal. (B. and C., 339358; Casebook, 13-14.)

XXIX. Appraisal of National Capitalism. (B. and C., 359-368; Casebook, 14-15.)

XXX. General Review; the Philosophy of Capitalism. (B. and C. 368-372.)

The present workbook is multilithed on loose-leaf sheets and punched for an $81 / 2 \times 11$-inch notebook. The questions are numbered serially for each unit and are printed in a column on the left-hand side of the page. They are adequately spaced so that the student may write the answers to the right of the questions. Also, the questions are listed under several main topics which represent a skeleton outline of the lesson.

The purpose of printing the questions in a column is to encourage a quick review by the student before class as well as before regular examinations. It is suggested to the student that he cover his answers with a blank piece of paper, set a time limit, and write only brief phrases as answers to the questions. The reason for this suggestion is two-fold. Writing within a time limit helps to duplicate the atmosphere of a classroom quiz where a student must write rapidly, often under a feeling of pressure. This is a real problem to some students during their first semester in a university. Also, if a student writes only brief phrases for the answers, he can answer all the questions in the assignment within a few minutes. When the student has completed this practice test, he should check the questions which need further review. Later he should take time to quiz himself on those questions which he missed in his first practice test. Most students have found this form of review quite helpful. In reply to a recent questionnaire almost every student stated that he was following this method.

In the same questionnaire, four out of every five students indicated that they used the questions as a guide to their reading of the textbook Business and Capitalism and the cases assigned from the Case- 
book in American Business History. To an instructor this might not seem very desirable because most students will be tempted to read only for the purpose of answering assigned questions. The instructor can handle this problem in the classroom by introducing other points for discussion.

There is another method of using the workbook. The student is urged to read the assignment at one sitting without taking notes, then to write the answers in the workbook without reference to the textbook. The next step is to compare these answers with the textbook and make the necessary changes. He is then prepared to review as described above. As one might expect, this procedure is not popular. It takes longer to prepare a lesson. In answer to the questionnaire only one out of every four students reported using the workbook questions in this fashion. Nevertheless it is highly recommended by the teaching staff.

An illustration of the questions and outline is given below. The spacing used for the answers is omitted. The questions in most units vary from ten to twenty, depending upon the nature of the material.

\section{Unit V. The Sedentary Merchant}

Gras, Business and Capitalism, 67-85.

Gras and Larson, Casebook, 5-7.

\section{A. Birth of Control in Private Business.}

1. How did the sedentary merchant differ from the traveling merchant?

2. Name the two general types of sedentary merchants.

3. What is the difference between the retail handicraft and the wholesale handicraft systems?

4. What was the significance of the sedentary merchant's purchasing from the wholesale handicraftsman?

5. How did the handicraftsmen oppose the growing control of sedentary merchants?

\section{B. Policy and Management of the Sedentary Merchant.}

6. List and describe the commercial functions of the sedentary merchant.

7. What kind of management problems did the sedentary merchant face in procuring desired goods to sell?

\section{Partnership Flourishes.}

8. List the three kinds of partnership used by sedentary merchants.

9. Show how terminal partnerships were quite flexible. 
The loose-leaf feature of the workbook is popular with both the students and the teachers. Each unit is to be completed at the beginning of the class period for which it is assigned. Without further announcement the instructor may call for the assigned unit. As a matter of practice, from one-third to one-half of the units are taken up and graded. Occasionally a short quiz is substituted. These grades are averaged and recorded as the grade for the entire workbook. This system of spot-checking proves quite satisfactory; among other things, it is adequate to induce students to read their lesson carefully before class.

The workbook also serves another purpose for the teacher. At the beginning of the discussion period the instructor may ask the students to state the questions they would prefer to have discussed. There are always a number of students who respond immediately. Even the shy student soon learns to speak up; he sees that it is to his advantage.

The first criterion used in selecting the case studies was that it should supplement the textbook, Business and Capitalism, on some point that appeared to need elaboration. Secondly, each case study was reviewed from the standpoint of the freshman student and his limited background. Finally, the author of the workbook wrote both questions and answers for the several case studies to ascertain their adaptability. The number of case studies selected was limited to nine so that the total number of units in the course would not exceed thirty.

During the past semester the students voted on their reaction to the case studies. The least popular were shown to be the Sir Thomas Smythe and mercantilism cases. All other case studies included in the workbook were preferred by three times as many students. Of course, the student preference should be discounted somewhat. It was found that nearly every student also voted to add more background material in the course in United States history. The events of the past century and a half appear more worthwhile to most students. The four most popular case studies are those on John Jacob Astor, Samuel Slater, Jay Cooke, and James J. Hill.

Meanwhile, the instructors have used one other feature, namely, a book review written in class without any notes. The purpose is to have the student read one brief book on current economics. It is 
desirable to relate the book report to the last few class assignments, although this has been very difficult to do. The students by a vote of three to one prefer that the book review be retained, however. The list of books used at present is:

C. E. Ayres, The Divine Right of Capital

Stuart Chase, The Road We are Traveling, 1914-42

Stuart Chase, Goals for America

Stuart Chase, Where's the Money Coming From?

Stuart Chase, Tomorrow's Trade

Stuart Chase, For This We Fought

Henry Hazlitt, Economics in One Lesson

Sidney Hook, The Meaning of Marx

Eric Johnston, America Unlimited

David Lilienthal, Democracy on the March

Peter Drucker, The Concept of the Corporation

J. M. Clark, The Alternative to Serfdom

As a result of this experiment the required course in freshman economics for business administration students has been changed from economic history to business history. Dr. Kennedy is now revising the workbook on the basis of this experience. It will be rewritten as a syllabus together with loose-leaf sheets for assignments. The references in Business and Capitalism and in the Casebook will be approximately the same. The questions will be rewritten and grouped under the main points of the outline, all on one page. The students will have loose-leaf sheets on which they will be instructed to elaborate the printed outline by answering the questions in a brief outline form. It is expected that this procedure will retain the usefulness of the loose-leaf workbook in use at present. At the same time, instead of merely answering questions, the student will be encouraged to make an outline suitable for review purposes. In addition to the questions in the revised syllabus calling for brief factual answers, each unit will have several broad questions for oral discussion in class. Two units of this revision were used by the students this spring. They voted that the change was a good improvement. Copies of the new syllabus will be available in May, 1948.

C. J. KenNedy

Department of Economics

College of Business Administration University of Nebraska 